\title{
FITTING BASELOAD AND PEAKLOAD FUTURES CONTRACTS TO FUTURE PLANNED ENERGY DEMAND
}

\section{Dominik Kudyba}

\begin{abstract}
In connection with the ongoing process of liberalization in the Polish electricity market, customer orientation and its needs are becoming an important competitive advantage of electricity trading companies.

The aim of this article is an attempt to present and solve the problem of fitting baseload and peakload futures contracts to future planned energy demand as a multicriteria programming problem. Due to the large number of variables and nonsmooth criteria the Monte Carlo simulation was used to solve the problem.

The model has been built to minimize price and imbalance volume between future planned demand and standard products able to purchase on the Polish commodity market. Due to future SPOT, the settlement simulation model requires future SPOT prices.
\end{abstract}

Keywords: electricity, hedging, multicriteria optimization, electricity futures contracts.

JEL Classification: C44.

DOI: $10.15611 / \mathrm{me} .2013 .9 .03$.

\section{Polish electricity market and basic definitions}

The liberalization of the electricity market in Poland started in April 1997 with the passing of the Energy law. At present the market's structure is more transparent, although electricity suppliers face the problem of insufficient market's liquidity and legal-administrative difficulties still affecting the structure of the market.

Electricity is a specific commodity, its characteristics include (Michalski, Krysta, Lelątko 2004):

- lack of storage capacity;

- continuous balance between supply and demand;

\section{Domink Kudyba}

Department of Operations Research. University of Economics in Katowice, ul. 1 Maja 50, 40-287

Katowice, Poland.

E-mail: kudybad@gmail.com 
- long-term investment process and the consequent lack of a significant increase in supply in the short term;

- investment in generation capacity and transmission lines requires large capital outlay;

- close link between commodity products (baseload, peakload);

- no short term price elasticity of demand.

One of the key elements allowing customers to access the energy market is the Third Party Access policy - TPA. Due to TPA policy, energy purchase has been separated from its transmission. In practice we are allowed to buy electricity from any energy selling company which is not necessarily also the distributor. TPA increases the development of competition in the electricity market ${ }^{1}$. Before TPA, customers had to conclude comprehensive agreements covering both the purchase of electricity and transmission services with the same company. Currently each consumer may conclude a separate agreement to purchase electricity from any electricity selling company in Poland. However, electricity has to be transmitted via the power infrastructure of a local distributor. So a transmission service agreement must be concluded between the consumer and its local distributor. Nowadays in Poland it is mostly customers with a relatively high energy consumption level who decide to use TPA policy.

Generally, a hedging problem originates from financial markets (Goldberg et al. 2007) and is widely described in literature. (Gotham et al. 2009) use the Markowitz theory (Mean-variance analysis) for electricity generation optimization. Standard volatility criterion: variance may be replaced by other measures like Value at Risk (VaR). This has been shown in (Oum, Oren 2009) and (Deng, Xu 2009). The article proposes a definition of the hedging problem as a multicriteria model capturing the direct relation between the electricity buyer and seller.

Here the basic definitions used in the article are presented.

Electricity buyer (customer, consumer) is anyone using electricity for final consumption (for example a household, enterprise, factory, public agency etc.). However, in this paper we focus on companies with high energy consumption rather than a household. Energy consumption is correlated with costs, thus a high level of consumption generates high costs and mostly large factories are interested in using TPA policy - the least price gives lower costs.

\footnotetext{
${ }^{1}$ Source: http://www.toe.pl/cache/2/40/222/ [2012-04-24].
} 
Electricity seller (energy trading company) - energy trading enterprise. There is a very important assumption: this enterprise cannot produce electricity by itself (the electricity seller is not a generation unit). The enterprise can buy or sell energy on the market.

Future planned demand - large electricity consumers are able to plan their future electricity demand for every hour. They usually use historical consumption data and information about production plans. The structure of future planned demand is highly heterogeneous. For example, demand planned for the year 2013 is a matrix with 365 rows (number of days in 2013 ) and 24 columns ( 24 hours a day). An example of future planned demand in the form of a matrix is shown in Figure 4.

Standard products - futures in the Polish commodity derivatives market. There are baseload and peakload futures. According to Polish Power Exchange, baseload futures means equal amounts of energy in each hour of the supply period ${ }^{2}$. Peakload futures includes supply only in working days in hours from 07:00 am to $10: 00 \mathrm{pm}^{3}$. A graphical representation of baseload and peakload is shown in Figures 1 and 2 respectively.

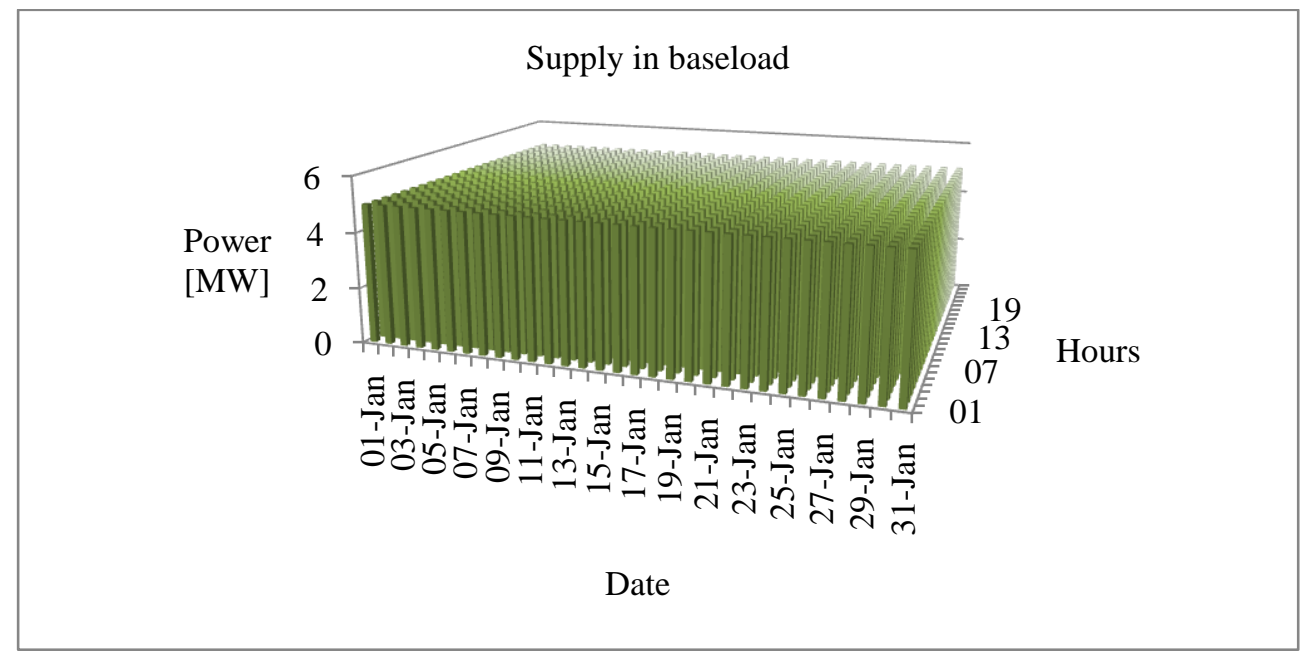

Fig. 1. Supply in baseload: electric power 5 MW, supply period January 2012

Source: own elaboration.

\footnotetext{
${ }^{2}$ Source: http://tge.pl/pl/42/rynek-terminowy-towarowy [2012-04-24].

${ }^{3}$ Source: Polish Energy Exchange website http://tge.pl/p1/42/rynek-terminowy-towarowy [2012-04-24].
} 


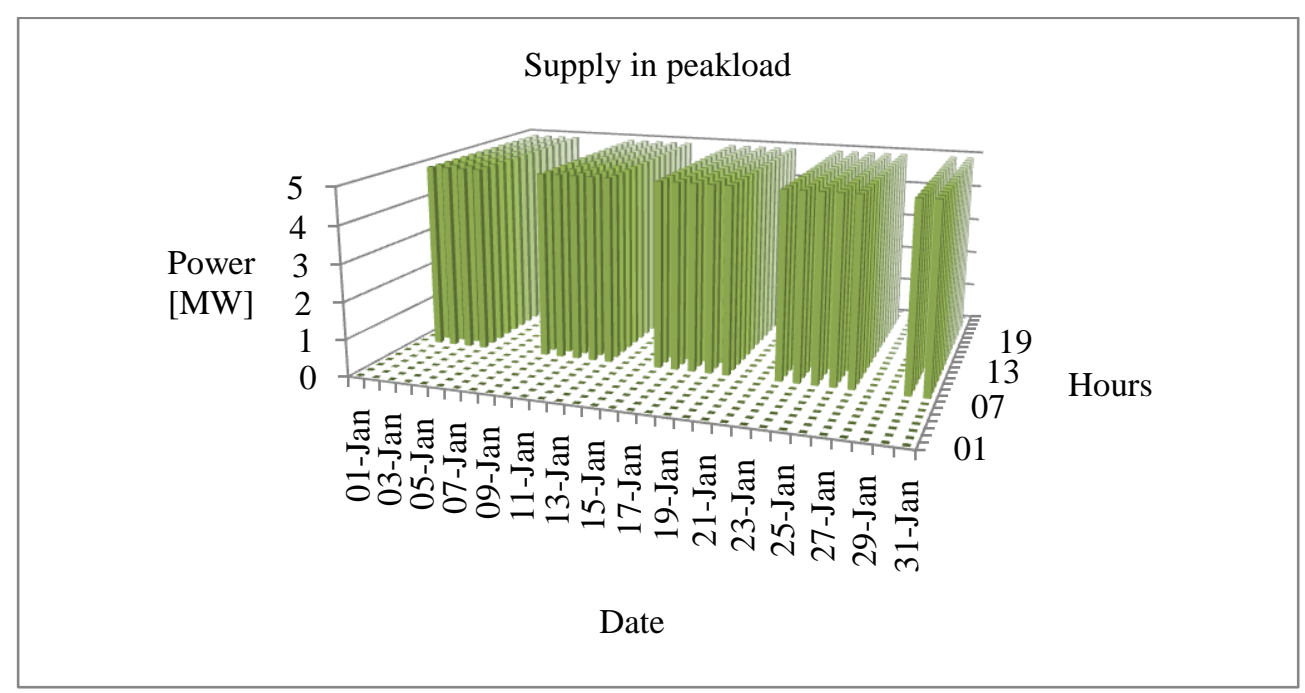

Fig. 2. Supply in baseload: electric power 5 MW, supply period January 2012

Source: own elaboration.

Futures profile - combination of standard products, the structure of futures profile is highly homogeneous.

Imbalance volume is the hourly difference between future planned demand and standard products fitted for this demand (futures profile). There is always some imbalance volume between electricity consumption and futures profile.

\section{Energy contracting process}

The energy contracting process is a set of coordinated activities aimed at hedging future planned demand. By hedging we mean buying electricity in the market for a particular customer. There is no general pattern of contracting electricity, methods can vary significantly depending on the details in the concluded trade agreements. However we are considering a situation where the potential customer provides a plan with future demand and the seller analyzes these data for hedging possibilities - trying to fit in some futures profile. The customer receives an offer with a fixed price.

Hedging is carried out in the commodity derivatives market ${ }^{4}$. There are two main reasons for hedging energy with futures contracts:

\footnotetext{
${ }^{4}$ There is a segment with futures contract in Polish Power Exchange. For more information please visit: http://tge.pl/en/42/rynek-terminowy-towarowy.
} 
- in this type of market today we can buy energy for a whole month, a quarter, even a year ahead;

- price is fixed for all the supply period.

A future energy demand plan with fitted futures profile is shown in Figure 3. The dashed line represents the imbalance volume between the future demand plan and the futures profile.

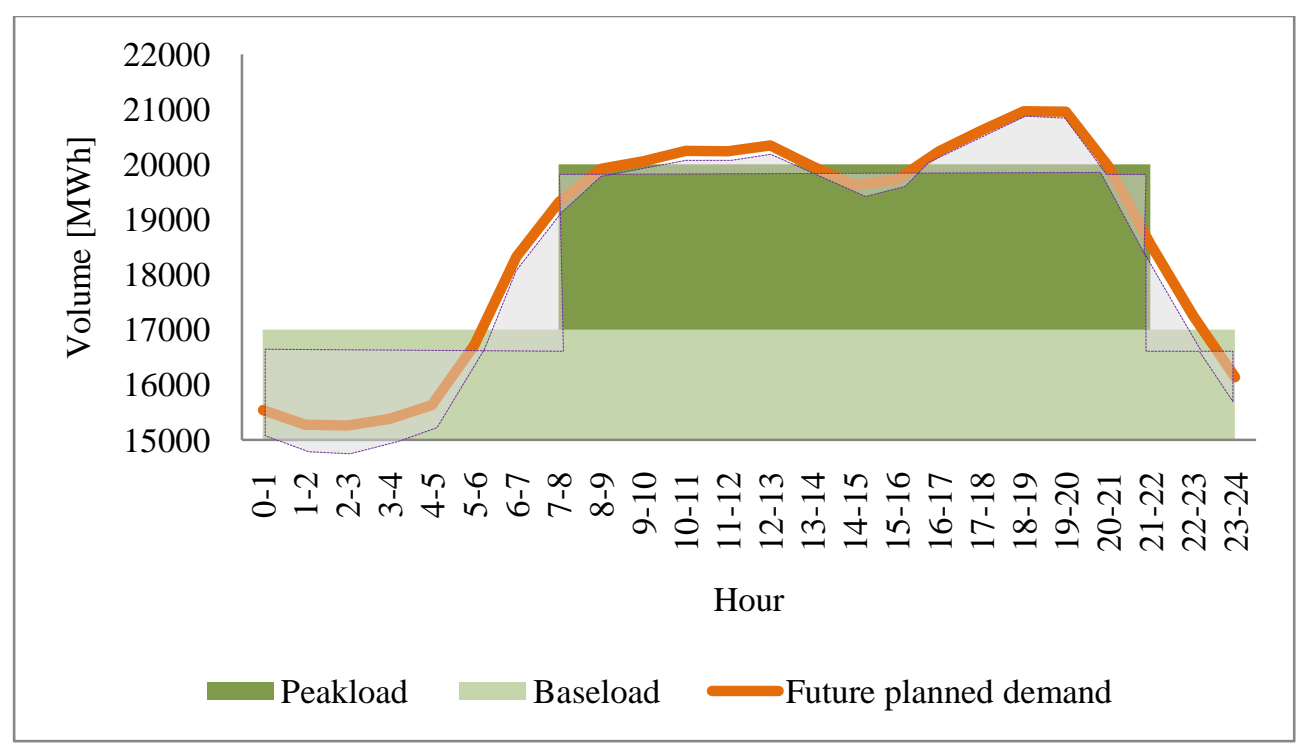

Fig. 3. Future energy demand plan with fitted futures profile and imbalance volume

Source: own elaboration.

We cannot hedge the imbalance volume in the same way - there is only the SPOT market ${ }^{5}$ where today we can only buy energy for a particular hour in the next day. So we do not know the price for periods further than tomorrow and this is very risky. It seems reasonable to fit in such a futures profile minimizing the imbalance volume and in addition a low offer price increases seller competitiveness. High price compensates the risk, this is obvious. Although if the offer price is too high, the potential customer will go to the competition. Therefore the trading company should take into account the possibility of minimizing the offer price as well.

\footnotetext{
${ }^{5}$ By SPOT market we mean a Day-Ahead Market and balancing market. For more information please visit: http://tge.pl/en/39/rynek-dnia-nastepnego and http://www.ure. gov.pl/palm/pl/217/1183/1_Model_rynku_energii_elektrycznej.html.
} 
Let us suppose that there is a factory with a high energy consumption level. The factory consumes relatively more energy in peak hours (from 7:00 am to 10:00 pm in working days) compared to off-peak hours (all other hours). The factory presents its future energy planned demand to the energy trading company (energy seller), and as a feedback the company presents its offer to the factory. Preparing the offer involves a futures profile fitting regarding the structure of future planned demand. The seller should maximize the fit of the futures profile so that the imbalance volume for the SPOT market is minimal. We also assume that the planned demand will not change significantly during supply.

\section{Future planned demand}

\begin{tabular}{|lc|c|c|c|c|c|c|c|c|c|c|c|c|}
\hline Date/Hour & \multicolumn{1}{c}{ Day -6 } & $\mathbf{6 - 7}$ & $\mathbf{7 - 8}$ & \multicolumn{3}{c|}{$\mathbf{8 - 9}$} & $\mathbf{9 - 1 0}$ & $\mathbf{1 0 - 1 1}$ & $\mathbf{1 1 - 1 2}$ & $\mathbf{1 2 - 1 3}$ & $\mathbf{1 3 - 1 4}$ & $\mathbf{1 4 - 1 5}$ & $\mathbf{1 5 - 1 6}$ \\
\hline 2012-01-01 & Saturday & 5,2 & 5,8 & 5,8 & 5,4 & 5,4 & 5,3 & 5,2 & 5,8 & 5,3 & 5 & 5,7 \\
\hline 2012-01-02 & Sunday & 5,6 & 5,5 & 5,6 & 5,3 & 5,6 & 5,9 & 6 & 5,9 & 5,4 & 5,8 & 5,9 \\
\hline 2012-01-03 & Monday & 5,1 & 5,5 & 7,7 & 7,7 & 7,7 & 7,9 & 7,6 & 7,3 & 7,6 & 7,9 & 7,6 \\
\hline 2012-01-04 & Tuesday & 5,8 & 5,2 & 7,3 & 8 & 7,4 & 7,6 & 7,7 & 7,5 & 7 & 7,6 & 7,9 \\
\hline 2012-01-05 & Wednesday & 5,2 & 5,5 & 7,4 & 7,6 & 7,5 & 7,1 & 7,7 & 7,3 & 7,1 & 7,3 & 7,6 \\
\hline 2012-01-06 & Public holiday & 5,1 & 5,8 & 5,6 & 6 & 6 & 5,8 & 5,5 & 5,4 & 5 & 5,5 & 5,5 \\
\hline 2012-01-07 & Friday & 5,1 & 5,2 & 7,7 & 7,6 & 7,6 & 7,7 & 7,5 & 7,3 & 7,7 & 8 & 7,6 \\
\hline
\end{tabular}

Fig. 4. An example of future energy planned demand

Source: own elaboration.

Futures profile

\begin{tabular}{|lc|c|c|c|c|c|c|c|c|c|c|c|}
\hline Date/Hour & \multicolumn{1}{c|}{ Day } & 5-6 & $\mathbf{6 - 7}$ & $\mathbf{7 - 8}$ & $\mathbf{8 - 9}$ & $\mathbf{9 - 1 0}$ & $\mathbf{1 0 - 1 1}$ & $\mathbf{1 1 - 1 2}$ & $\mathbf{1 2 - 1 3}$ & $\mathbf{1 3 - 1 4}$ & $\mathbf{1 4 - 1 5}$ & $\mathbf{1 5 - 1 6}$ \\
\hline $2012-01-01$ & Saturday & 5 & 5 & 5 & 5 & 5 & 5 & 5 & 5 & 5 & 5 & 5 \\
\hline $2012-01-02$ & Sunday & 5 & 5 & 5 & 5 & 5 & 5 & 5 & 5 & 5 & 5 & 5 \\
\hline $2012-01-03$ & Monday & 5 & 5 & 7 & 7 & 7 & 7 & 7 & 7 & 7 & 7 & 7 \\
\hline $2012-01-04$ & Tuesday & 5 & 5 & 7 & 7 & 7 & 7 & 7 & 7 & 7 & 7 & 7 \\
\hline $2012-01-05$ & Wednesday & 5 & 5 & 7 & 7 & 7 & 7 & 7 & 7 & 7 & 7 & 7 \\
\hline $2012-01-06$ & Public holiday & 5 & 5 & 5 & 5 & 5 & 5 & 5 & 5 & 5 & 5 & 5 \\
\hline $2012-01-07$ & Friday & 5 & 5 & 7 & 7 & 7 & 7 & 7 & 7 & 7 & 7 & 7 \\
\hline
\end{tabular}

Fig. 5. An example of futures profile

Source: own elaboration. 
For computational reasons, both the plan of demand and plan of supply (as a result of futures profile fitting) are presented as matrices. In Figures 4 and 5 we have examples of a plan of demand and supply as a matrix in the period from 1 to 7 January 2012.

\section{Problem definition}

The problem focused in fitting demand structure to the futures profile can be formulated as a multicriteria model with two objective functions: imbalance volume and the offered price, both to be minimized.

$$
\begin{aligned}
& \operatorname{MIN}\left\{\left|\left(x_{\text {base }} \cdot P_{i \times j}\right)+\left(x_{\text {peak }} \cdot S_{i \times j}\right)-Z_{i \times j}\right|\right\}
\end{aligned}
$$

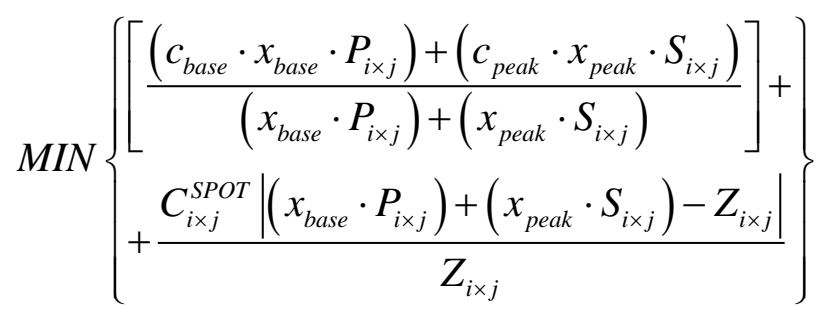

$$
\begin{aligned}
& \left\{\begin{array}{l}
\min \left(\left(P_{i \times j}-S_{i \times j}\right) Z_{i \times j}\right) \leq x_{\text {base }} \leq \max \left(\left(P_{i \times j}-S_{i \times j}\right) Z_{i \times j}\right) \\
\min \left(S_{i \times j} \cdot Z_{i \times j}\right) \leq x_{\text {peak }} \leq \max \left(S_{i \times j} \cdot Z_{i \times j}\right)
\end{array}\right.
\end{aligned}
$$

Decision variables:

$x_{\text {base }}$ - baseload power;

$x_{\text {peak }}$ - peakload power;

Available data:

$Z_{i \times j}$ - future energy planned demand matrix;

$c_{\text {base }}$ - futures' baseload price;

$c_{\text {peak }}$ - futures' peakload price;

$C_{i \times j}^{S P O T}-$ SPOT prices matrix;

$i$-days index, for example $i=1, \ldots, 8760$ for supply in year 2012;

$j$-hours index in $i$-th day, $j=1, \ldots, 24$;

$P_{i \times j}$-baseload supply matrix;

$S_{i \times j}$ - peakload supply matrix. 
Supply matrices have binary values. When there is supply in $i$-th day and $j$-th hour, then the value is 1 otherwise the value is 0 . Matrix $P_{i \times j}$ is filled by value 1 , because baseload means supply in each hour of the supply period. Matrix $S_{i \times j}$ has 1 at the intersections of the columns from 8 to 22 (representing hours from 7:00 am to 10:00 pm) and rows representing the working days (Mondays to Fridays without public holidays). The other elements of matrix $S_{i \times j}$ are filled with 0 .

Criterion (1) is responsible for minimizing the imbalance volume calculated as a module sum of the differences between the futures profile and the planned demand for energy.

Criterion (2) consists of two parts. The first part is related to the commodity derivatives market - this is the volume weighed average price of the futures profile. The second part concerns the imbalance volume settlement in the SPOT market. SPOT prices are weighed here by planned demand volume.

Constraint (3) defines the search range for baseload electric power. The values of the minimum and maximum electric power are chosen from offpeak zone in planned demand.

The last constraint (4) defines a search range for peakload electric power, its values are chosen from the peak zone in planned demand.

\section{The proposal of the solution}

We may consider the model described above in many different categories. Generally this is a linear problem, although module differences indicate the non-differentiable nature of criteria. Additionally, future SPOT prices may be considered as a long-term forecast, and then we have stochastic elements in our model. A computer simulation is proposed to solve the problem as one of the most effective methods in this case.

We have a factory with a future energy planned demand volume in the year 2012 equal to $545215.75 \mathrm{MWh}$. This amount of energy corresponds to the baseload power at level $62.1 \mathrm{MW}$ - so this is a relatively high consumption.

The assumptions for simulations are:

- A futures profile consists of baseload and peakload futures contracts.

- Electric baseload power is a search in interval $\langle 32,4 ; 59,6\rangle \mathrm{MW}$, power is rounded to $0,1 \mathrm{MW}$.

- Electric peakload power is a search in interval $\langle 56,4 ; 119,5\rangle \mathrm{MW}$, power is rounded to $0,1 \mathrm{MW}$.

- Baseload futures contract price is 203, 24 PLN/MWh.

- Peakload futures contract price is 210, 83 PLN/MWh. 
- Simulation for 10000 iterations.

- Future SPOT prices are calculated using the Ornstein - Uhlenbeck model (Iacus, 2007).

In Figure 6 there is a part of criterion space and in Table 1 there are 10 filtrated solutions with the least imbalance volume and corresponding price.

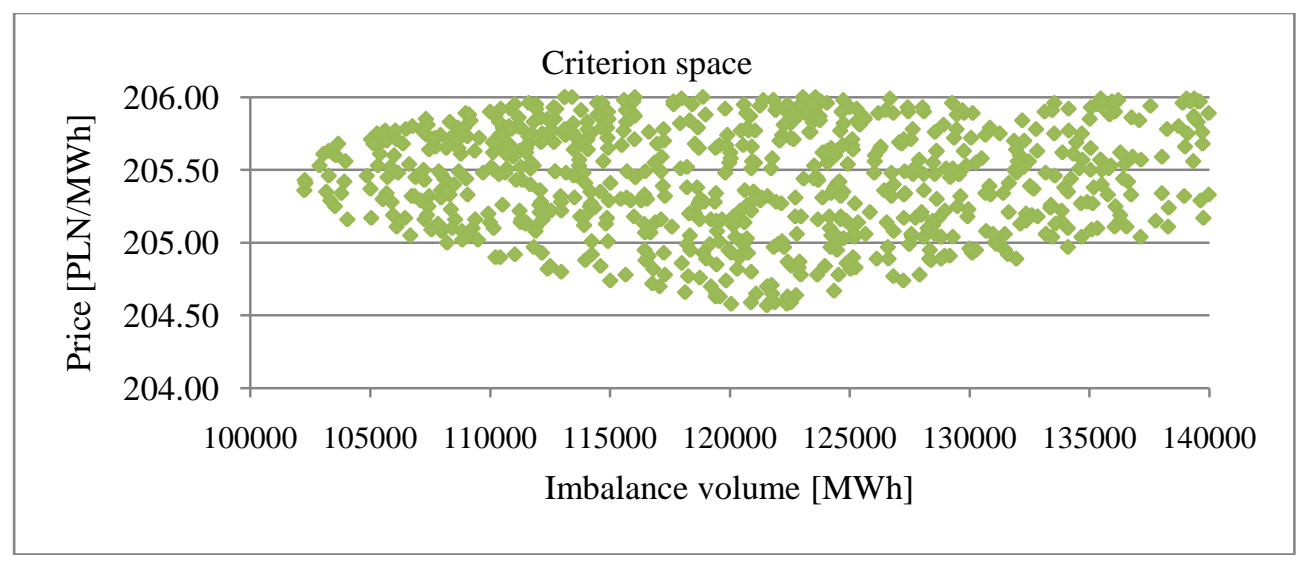

Fig. 6. Criterion space

Source: own elaboration.

Table 1. Results

\begin{tabular}{|c|c|c|c|c|c|c|}
\hline Solution & $\begin{array}{c}\text { Imbalance } \\
\text { volume } \\
{[\mathrm{MWh}]}\end{array}$ & $\begin{array}{c}\text { Price } \\
\text { [PLN/MWh] }\end{array}$ & $\begin{array}{c}\text { Baseload } \\
\text { power } \\
\text { [MW] }\end{array}$ & $\begin{array}{c}\text { Peakload } \\
\text { power } \\
{[\mathrm{MW}]}\end{array}$ & Iteration & $\begin{array}{c}\text { Imbalance to } \\
\text { demand volume } \\
\text { ratio [\%] }\end{array}$ \\
\hline 1 & 102251,61 & 205,36 & 40,9 & 56,5 & 4917 & $18,75 \%$ \\
\hline 2 & 102269,13 & 205,43 & 41,6 & 56,6 & 2599 & $18,76 \%$ \\
\hline 3 & 102301,67 & 205,41 & 41,4 & 56,6 & 7273 & $18,76 \%$ \\
\hline 4 & 102882,93 & 205,53 & 42,4 & 56,8 & 5734 & $18,87 \%$ \\
\hline 5 & 103045,63 & 205,61 & 43,4 & 56,6 & 3114 & $18,90 \%$ \\
\hline 6 & 103162,53 & 205,35 & 40,6 & 56,8 & 4748 & $18,92 \%$ \\
\hline 7 & 103257,27 & 205,63 & 43,6 & 56,6 & 373 & $18,94 \%$ \\
\hline 8 & 103269,71 & 205,46 & 41,6 & 57 & 7503 & $18,94 \%$ \\
\hline 9 & 103333,45 & 205,29 & 40,1 & 56,7 & 4371 & $18,95 \%$ \\
\hline 10 & 103479,37 & 205,61 & 43,3 & 56,8 & 5540 & $18,98 \%$ \\
\hline
\end{tabular}

Source: own elaboration.

Two solutions have been found after 7000 iterations, so 10000 iterations is rather the proper level. The imbalance volume is mostly near to $19 \%$ of the planned demand. Solution number 9 has the lowest price of 205,29 PLN/MWh with imbalance volume $103333,45 \mathrm{MWh}$ and this is 18,97\% of planned demand (corresponding to a baseload with power 11,8 MW). 


\section{Conclusions}

A computer simulation is a relatively simple tool to solve such problems. Its implementation in a spreadsheet enhances the model's flexibility. We can easily change the constraints and criteria, although the simulation of complex models is unfortunately associated with increased computing time. In some cases this may be an insurmountable obstacle. The considered simulation model includes fitting only with the peakload and baseload profiles. Adaptation to the requirements of customers and suppliers through new standardized futures contracts is the normal tendency for each commodity market, especially in new markets of non-mature structure.

\section{References}

Bunn W.D. (2004). Modeling Prices in Competitive Electricity Markets. John Wiley \& Sons.

Deng S-J., Xu L., (2009). Mean-risk efficient portfolio analysis of demand response and supply resources. Energy 34. Elsevier. Pp. 1523-1529.

Fusaro P. (2008). The professional risk managers guide to the energy market. PRIMA Institute.

Goldberg R., Read J., Altman A., Audouin R. (2007). Delta hedging energy portfolios: an exploratory study. Proceedings of the 40th Hawaii Conference on system sciences.

Gotham D., Muthuraman K., Preckel P., Rardin R., Ruangpattana S. (2009). A load factor based mean-variance analysis for fuel diversification. Energy Economics 31. Elsevier. Pp. 249-256.

Iacus S.M. (2007). Simulation and inference for stochastic differential equations with $R$ examples. Springer.

James T. (2007). Energy market. Price risk management and trading. Willey.

Kaminski V. (2004). Managing Energy Price Risk. Risk Publications.

Kaminski V. (2005). Energy Modeling. Advances in the Management of Uncertainty. Risk Publications.

Jajuga K., Jajuga T. (2009). Inwestycje. Instrumenty finansowe, ryzyko finansowe, inżynieria finansowa. PWN.

Michalski D., Krysta B., Lelątko P. (2004). Zarządzanie ryzykiem na rynku energii elektrycznej. Instytut Doskonalenia Wiedzy o Ryku Energii. Warszawa.

Mielczarski W. (2000). Rynki energii elektrycznej. Wybrane aspekty techniczne i ekonomiczne. ARE S.A. Warszawa.

Oum Y., Oren S. (2009). VaR constrained hedging of fixed price load-following obligations in competitive electricity markets Risk and Decision Analysis 1. IOS Press and the authors. Pp. 43-56.

Weron A., Weron R. (2000). Giełda energii. Strategie zarządzania ryzykiem. CIRE. Wrocław.

\section{Websites}

Polish Power Exchange website: www.tge.pl [24.04.2012].

Association of Energy Trading website http://www.toe.pl/cache/2/40/222/ [2012-04-24].

Energy Regulatory Office website: http://www.ure.gov.pl [24.04.2012]. 